\title{
ANALISIS DAN DESAIN SISTEM INFORMASI PENGOLAHAN DATA KADER PADA FORUM PEMUDA PELAJAR MAHASISWA TANGERANG
}

\author{
Rohmat Taufiq ${ }^{1}$, Rachman Iswanto ${ }^{2}$, Liesnaningsih ${ }^{3}$, Budiono $^{4}$ \\ 1,2,3,4 Program Studi Teknik Informatika, Fakultas Teknik, Universitas Muhammadiyah Tangerang \\ Jl. Perintis Kemerdekaan 1/33 Cikokol Kota Tangerang \\ Co Responden Email: RohmatTaufik@gmail.com
}

Article history

Received Sept 22, 2020

Revised Nov 15, 2020

Accepted Feb 1, 2021

Available online Februari 28,

2021

Keywords

Design,

Informati

on

Systems,

Data

Collectio

$n$ and

Online

Riwayat

Diterima 22 Sept 2020

Revisi 15 Nov 2020

Disetujui 1 Feb 2021

Terbit 28 Februari

2021

Kata Kunci

Perancanga

n, Sistem

Informasi,

Pendataan,

Online

\begin{abstract}
The Tangerang Student Youth Forum, which still uses the manual system for processing cadre data, can sometimes slow down the performance of the Daily Executive Board $(B P H)$. The analysis method used is the interview method or interview, the method of observation, and the method of literature. And the design is done using the Unified Modeling Language (UML) method. The purpose of this research is to develop an information system processing data for cadres at the Tangerang Student Youth Forum to easily and efficiently manage data. The conclusion of this study shows that the processing of cadre data at the Tangerang Student Youth Forum requires a system that facilitates the performance of the Daily Management Board (BPH) so that it saves time and is easy to run and is more well organized.
\end{abstract}

\begin{abstract}
Abstrak
Forum Pemuda Pelajar Mahasiswa Tangerang yang masih menggunakan sistem manual pada pengolahan data kader, hal ini terkadang dapat memperlambat kinerja para Badan Pengurus Harian (BPH). Metode analisa yang digunakaan adalah metode interview atau wawancara, metode observasi, dan metode kepustakaan. Dan perancangan yang dilakukan dengan menggunakan metode Unified Modeling Language (UML). Tujuan dari penelitian ini adalah untuk mengembangkan sistem informasi pengolahan data kader pada Forum Pemuda Pelajar Mahasiswa Tangerang secara mudah dan efisien dalam pengelolaan data. Kesimpulan dari penelitian ini menunjukan bahwa pengolahan data kader pada Forum Pemuda Pelajar Mahasiswa Tangerang membutuhkan suatu sistem yang mempermudah kinerja Badan Pengurus Harian (BPH) sehingga menghemat waktu serta mudah dijalankan dan lebih terorganisir dengan baik.
\end{abstract}




\section{PENDAHULUAN}

Perkembangan ilmu dan teknologi mengalami kemajuan yang pesat dalam bidang informasi, seperti halnya pertukaran informasi, dapat dilihat dari proses pertukaran informasi yang paling sederhana yaitu komunikasi secara langsung sampai pada pertukaran informasi yang paling canggih seperti pertukaran dengan menggunakan internet. Dan seiring perkembangan teknologi tersebut manusia pun terus berusaha untuk meningkatkan kreatifitasnya dalam mempermudah proses pertukaran informasi, dengan menggunakan alat yang begitu canggih yang disebut dengan teknologi komputer.

Seperti halnya teknologi komputer, teknologi informasi merupakan salah satu teknologi yang sangat berkembang pesat saat ini. Teknologi informasi adalah salah satu teknologi yang didukung oleh teknologi komputer. Dengan kemajuan teknologi informasi, pengaksesan terhadap data atau informasi yang tersedia dapat berlangsung dengan efisien dan efektif. Pemanfaatan teknologi informasi secara menyeluruh dan terpadu dapat menghasilkan keuntungan dan meningkatkan efisiensi dan efektifitas suatu sekolah atau organisasi.

Forum Pemuda Pelajar Mahasiswa Tangerang (FPPMT) adalah salah satu lembaga yang bergerak dalam bidang Pendidikan, Lingkungan, Sosial dan Kesehatan. Berdasarkan Pengamatan penulis, mendata disetiap kegiatan yang dilaksanakan Forum Pemuda Pelajar Mahasiswa Tangerang masih dilakukan dengan proses manual dengan menggunakan Mc. Excel 2010 sehingga masih terdapat banyak kekurangan baik dari segi efisiensi maupun efektifitas.

\section{TINJAUAN PUSTAKA}

Analisis sistem menurut Jeffery adalah sebuah istilah yang secara koektif mendeskripsikan langkah-langkah awal pengembangan sistem (Taufiq, dkk 2019). Sedangkan menurut Jogiyanto (2005) analisis sistem dapat didefinisikan sebagai penguraian dari suatu sistem informasi yang utuh ke dalam bagian mengevaluasi permasalahan-permasalaha, kesempatan-kesempatan, hambatan-hambatan yang terjadi dan kebutuhan-kebutuhan yang diharapkan sehingga dapat diusulkan perbaikanperbaikannya. Tujuan analisis sistem informasi adalah untuk mendesain sistem baru atau menyempurnakan sistem yang sebelumnya sudah ada (Kadir, 2014)

Menurut Syifaun Nafiah (2003) Perancangan adalah penggambaran, perencanaan dan pembuatan sketsa atau pengaturan dari berbagai elemen yang terpisah ke dalam satu kesatuan yang utuh dan berfungsi. Sedangkan menurut Ambon Saragih (2015) "Perancangan adalah suatu langkah untuk memberikan gambaran secara umum kepada manusia atau pengguna tentang sistem yang diusulkan".

Sistem adalah suatu kumpulan atau himpunan dari unsur, komponen atau variabel yang terorganisasi, saling berinteraksi, saling tergantung satu sama lain dan terpadu. (Permana, 2016). Sistem informasi adalah kumpulan dari sub-sub sistem yang saling terintegrasi dan berkolaborasi untuk menyelesaikan masalah tertentu dengan cara mengolah data sehingga memiliki nilai tambah dan bermanfaat bagi pengguna (Taufiq, 2018).

Komponen-komponen sistem informasi menurut O'Brien (2005) terdiri dari Manusia, Hardware, Software, Data dan Jaringan.

Menurut Karim, A (2017) "Data adalah bahan mentah yang diproses untuk menyajikan informasi. Dan data juga suatu istilah majemuk yang berarti fakta atau bagian dari fakta yang mengandung arti yang dihubungkan dengan kenyataan, simbol, gambar, angka, huruf atau simbol yang menunjukkan suatu ide, objek, kondisi, atau situasi".

UML (Unified Modeling Language) adalah bahasa spesifikasi standar yang digunakan untuk mendokumentasikan, menentukan, dan membangun perangkat lunak (Destriana, Permana, Legawa, Irawan, 2018).

Sistem informasi berbasis web mampu memfasilitasi pengguna untuk menginput datadata yang berkaitan dengan sistem selain itu juga memberikan kemudahan para pengguna untuk mencari informasi secara real time (Syepry dkk, 2020). 


\section{METODE PENELITIAN}

Dalam metode penelitian ini yang dilakukan terdapat 6 langkah yang terdiri dari komunikasi, rencana, pengumpulan data, analisis, desan dan pembuatan laporan.

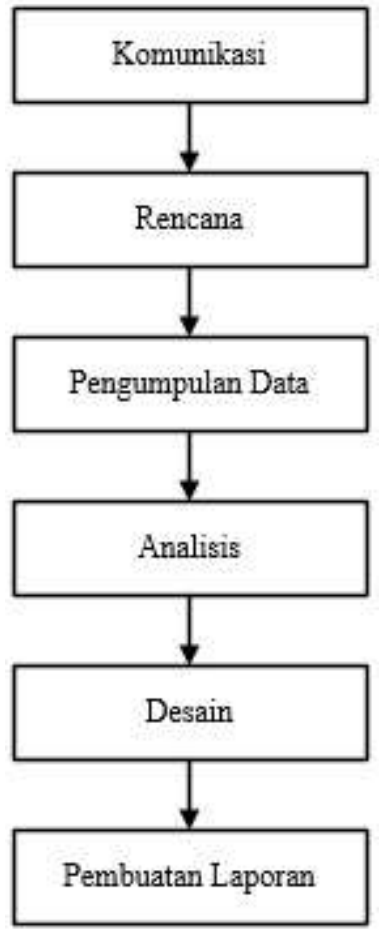

Gambar 1 Metode Penelitian

Komunikasi merupakan langkah awal dalam penelitian ini, yang dilakukkan dalam komunikasi untuk mengetahui sistem di perusahaan. Langkah selanjutnya yaitu rencana, yang dilakukan membuat perencanaan bagaimana cara menganalisis dan mendesain, alat apa yang dibutuhkan dan berapa lama waktu yang akan dipergunakan.

Langkah ketiga yaitu pengumpulan data, yang dilakukan dengan cara wawancara, observasi dan literatur. Langkah keempat yaitu analisis, yang dilakukan dalam analisis yaitu mengetahui bagaimana proses yang berjalan. Langkah kelima yaitu desain, yang dilakukan membuat desain logic dengan menggunakan Unified Modelling Language (UML) dan desain fisik dengan menggambar tampilan form yang diusulkan. Selain pembuatan UML dalam langkah ini juga melakukan proses perancangan sistem sampai dengan pengujian.

Langkah yang terakhir yaitu membuat laporan akhir yang bisa dijadikan sebagai acuan untuk mempelajari proses dari sistem atau dari laporan tersebut bisa digunakan untuk proses pengembangan dalam waktu yang akan datang.

HASIL DAN PEMBAHASAN Sistem yang Berjalan

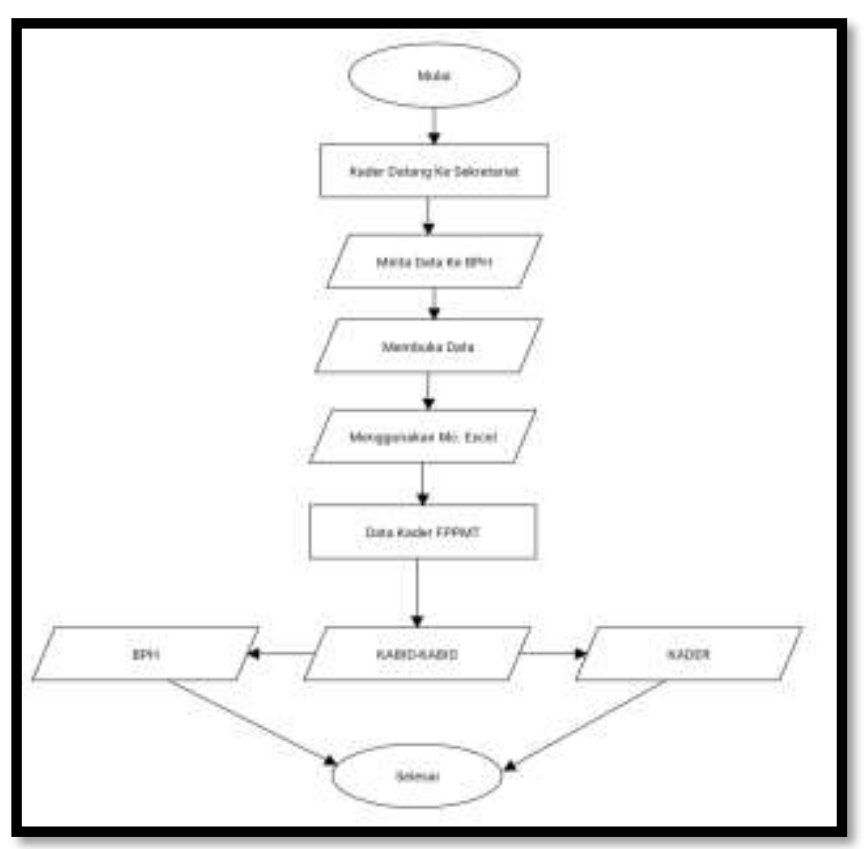

Gambar 2 Flowchart sistem yang berjalan

Proses-proses yang ada pada data kader Forum Pemuda Pelajar Mahasiswa Tangerang yaitu:

a) Kader atau kader baru datang ke sekretariat

b) Kader meminta kepada $\mathrm{BPH}$

c) $\mathrm{BPH}$ membuka data melaui Mc.Excel

d) Setelah kader baru mengetahui struktural kepengurusan FPPMT

e) Data tersebut didalamnya data ketua, kabid, anggota kader.

\section{Perancangan Sistem Use Case Diagram}




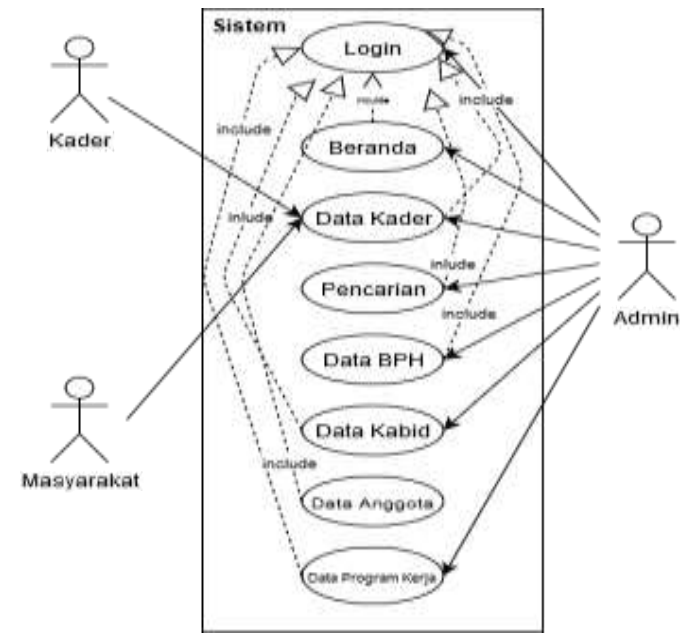

Gambar 3 Use Case Diagram

Dalam Use case diagram tersebut terdiri dari 3 aktor, yaitu Kader, Masyarakat serta Admin. Masing-masing aktor memilkiki hak akses yang berbeda-beda yang sudah disesuaikan dengan kebutuhannya.

\section{State Chart Diagram}

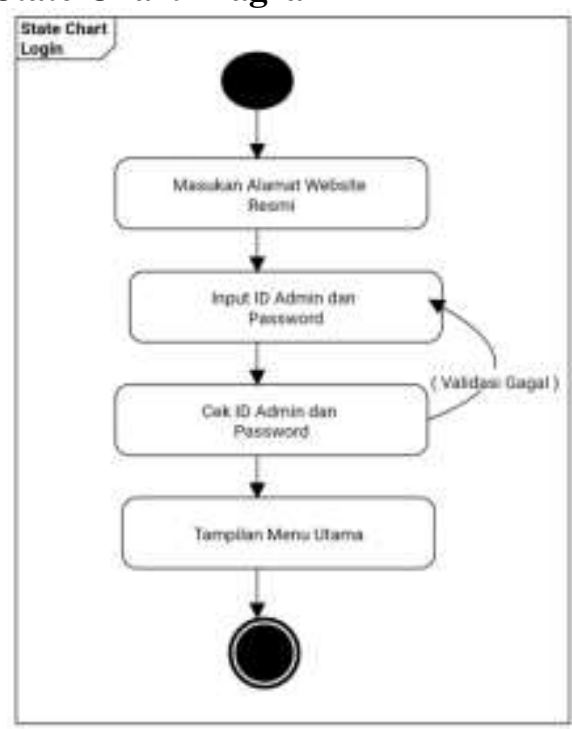

Gambar 4 Statechart Diagram Login

Statechart dalam gambar 4 tersebut menampilkan salah sastu statechart dari beberapa statechart yang ada. Statechart diatas menggambarkan bagaimana cara login ke sistem.

\section{Activity Diagram}

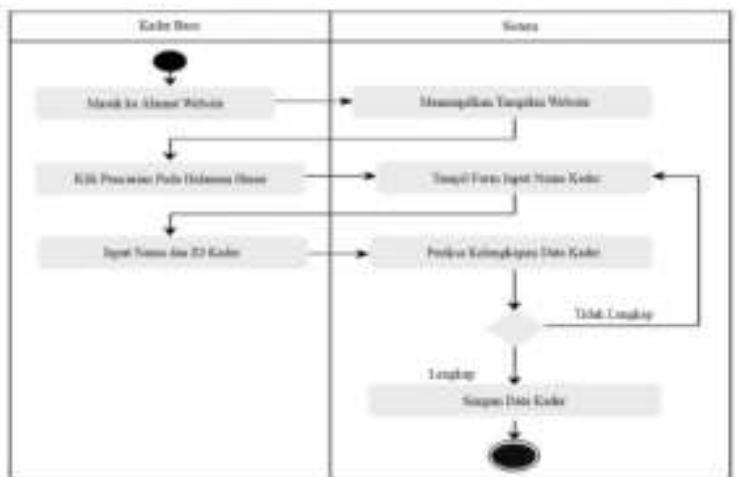

Gambar 5 Activity Diagram Input Data

Gambar 5 diatas menjelaskan activity diagram untuk input data anggota baru atau kader baru yang akan menjadi anggota baru Kader pada Forum Pemuda Pelajar Mahasiswa Tangerang (FPPMT).

\section{Sequence Diagram}

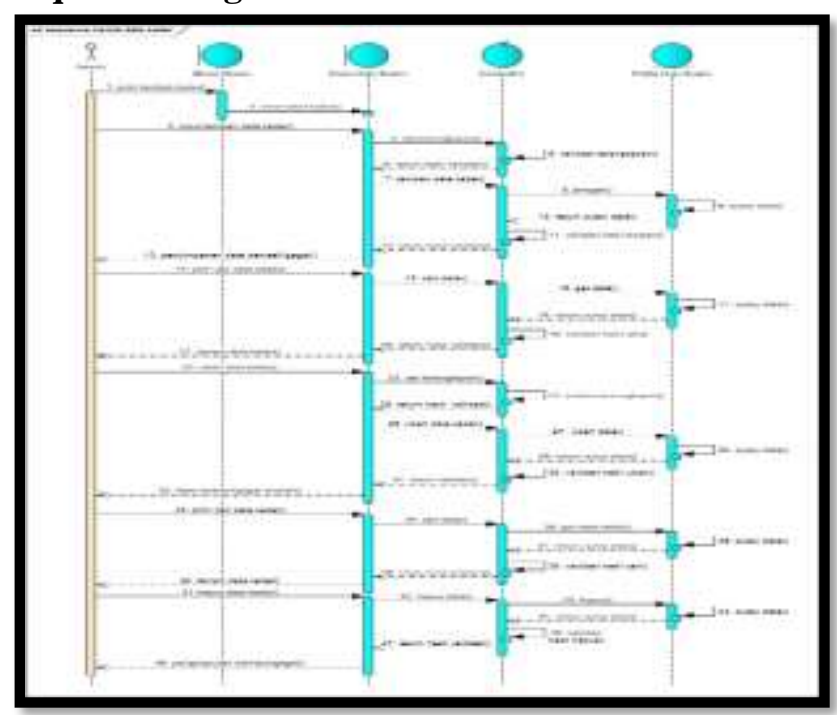

Gambar 6 Sequence Diagram Data Kader

Gambar 6 diatas menggambarkan sequence diagram untuk data kader. Dalam sequence diagram tersebut menjelaskan bagiamana seorang aktor menggunakan aplikasi sistem yang sudah dikembangkan. Masuk ke menu utama, lalu masuk ke form data kader setelah itu kontroler dan proses yang terakhir yaitu entitas data kader. 


\section{Implementasi}

Tampilan Login

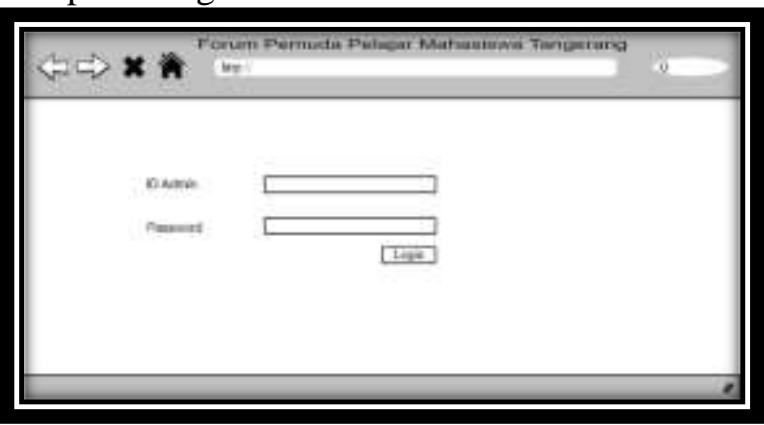

Gambar 7 Tampilan Login

Login tersebut di fungsikan oleh 3 type pengguna yang terdiri dari admin, kader dan masyarakat. Masing-masing pengguna memiliki user id yang berbeda-beda dan akses yang diberikan juga sudah dibatasi sesuai dengan ketentuan yang sudah disepakati.

Tampilan Data Ketua

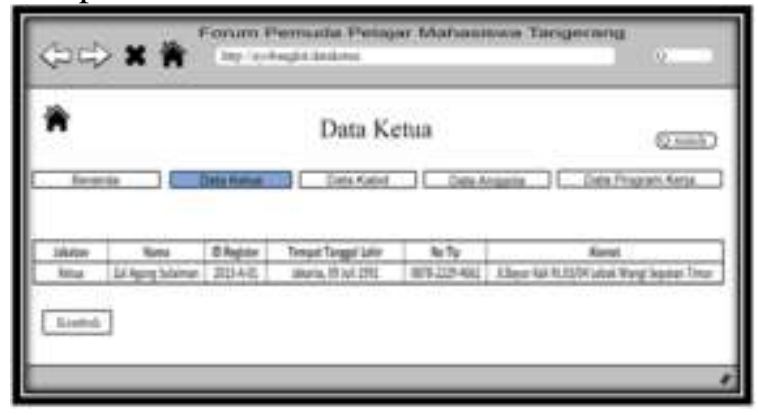

Gambar 8 Tampilan Data Ketua

Gambar 8 diatas menjelaskan bagaimana sebuah sistem menampilkan data ketua forum pemuda pelajar mahasiswa Tangerang (FPPMT).

Tampilan Data Kabid

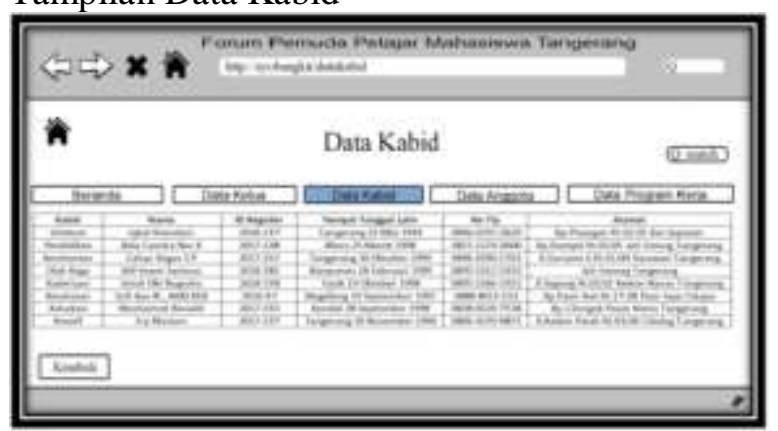

Gambar 9 Tampilan Data Kabid

Gambar diatas menjelasksn bagaimana sebuah sistem informasi menampilkan identitas data kepala bidang, yang di klasifikasikan menjadi kabid infokom, Pendidikan, krohanian, olah raga, kaderisasi, kesehatan, advokasi dan kreatif.

Tampilan Data Anggota Kader

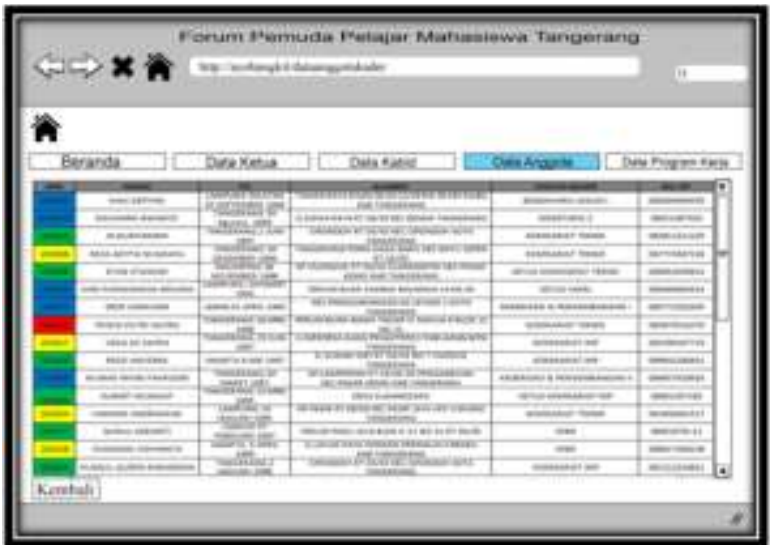

Gambar 10. Tampilan Data Anggota kader

Data anggota kader di tampilkan dalam gambar 10 diatas. Dimana aplikasi dari sistem ini menampilkan beberapa field yang terdiri dari Nama, Tempat Tanggal Lahir, Status Kader dan Nomor HP.

\section{Tampilan Program Kerja FPPMT}

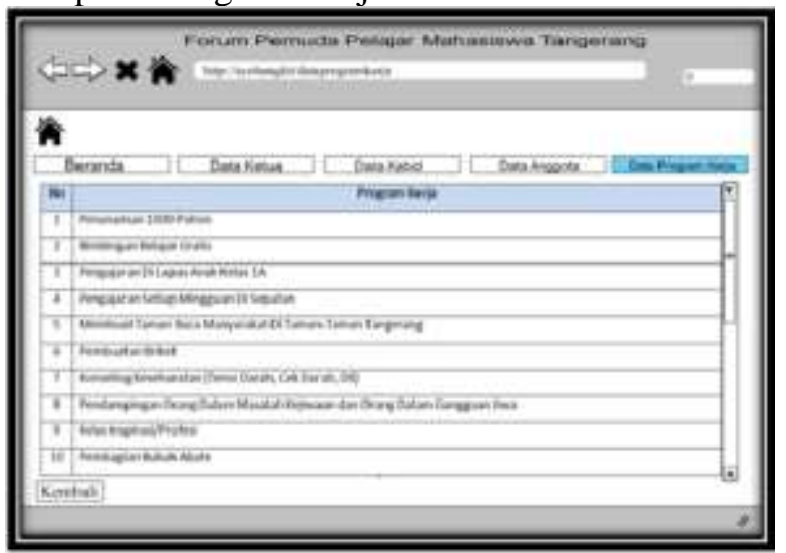

Gambar 11 Form Data Program Kerja

Rencana kegiatan forum pemuda pelajar mahasiswa di tungkan dalam program kerja. Terdapat banyak program kerja yang sudah dibuat mulai dari penanaman 1000 pohon, bimbingan belajar gratis, pengajaran di lapas anak kelas 1A sampai dengan kegiatan-kegiatan yang lainnya.

\section{KESIMPULAN}

Pada sistem yang berjalan di Lembaga Forum Pemuda Pelajar Mahasiswa Tangerang, kami merancang sistem pengolahan data ini secara online agar setiap kader dan kader baru mengetahui pengurus Fppmt dan Program Kerja Fppmt supaya lebih mudah dan memiliki rasa ingin bergabung dengan program kerja Fppmt. Dengan sistem pengolahan data ini yang terkomputerisasi dengan lebih baik lagi dapat menghasilkan informasi yang 
lebih cepat dan data-data yang berhubungan dengan sistem pengolahan data dapat tersimpan dengan baik dan hasilnya lebih cepat, tepat dan efisien, sehingga dapat mengurangi data yang hilang atau rusak dan proses pencarian datanya tidak memerlukan waktu yang lama.

\section{REFERENSI}

AZHARI, Lukman. Pemilihan Framework Aplikasi Web Berbasis Java Menggunakan Analytical Hierarchy Process (Ahp). JIKA (Jurnal Informatika), 2018, 2.1.

Destriana, R., Permana, A, A., Legawa, S, D,. dan Irawan, H. 2019, Security system development for vehicle using the method of "mail notification" at villa Rizki Ilhami Tangerang residential, IOP Conference Series: Materials Science and Engineering 012124, Vol 508 No 1, IOP Publishing doi:10.1088/1757-899X/508/1/012124.

Husain, SM. Azhari, L. Taufiq, R. Rahma, A (2020). Rancang Bangun Aplikasi ELibrary Fakultas Teknik Universitas Muhammadiyah Tangerang. Jurnal Informatika, E ISSN: 2722-2713 November 2020. Pp 64-72

Jogiyanto HM (2005). Analisis dan Desain. Penerbit Andi. Yogyakarta.

James A O'Brien (2005). Introduction to Information System, $12^{\text {th }}$ Editiion. Mc Graw Hill, USA.

Kadir, A. (2014). Pengenalan Sistem Informasi Edisi Revisi. Andi. Yogyakarta

Karim, A (2017) Sistem Informasi Pengolahan Data Kriminal Pada Kepolisian, Jurnal Ilmiah Infotek, 2. Amik Stiekom Sumatera Utara. ISSN: 2580-474X (E)

Permana, A. A. (2016). Rancangan Sistem Informasi Simpan Pinjam Pada Koperasi Guru dan Pegawai SMP Negeri 45 Jakarta. JIKA (Jurnal Informatika) Vol. 1 No.2 2017 ISSN 2549 - 0710.
Syifaun Nafiah (2003) Perancangan Aplikasi Toko Buku Online Berbasis Web Interaktif.

Saragih, A. (2015). Perancangan Aplikasi Pendataan Suplayer Getah Karet Pada PT.Rubber Hock Lie Menggunakan Visual Basic.NET. Jurnal INFOTEK, 30.

Taufiq, R. Maelani, N dan Liesnaningsih (2019). Analisis dan Desain Sistem Penerimaan Karyawan Baru Pada PT. Surya Toto Indonesia. Jurnal Teknik Informatika (JIKA) UMT. ISSN: 2519-0710. Februari 2019.

Taufiq, R (2018) "Pengantar Sistem Informasi”. Jakarta. Mitra Wacana Media. 